Tekşan, K. (2013). Türkçe öğretiminde eleştirel düşünmeyi geliştirme bakımından Ömer Seyfettin'in hikâyelerinin yeri. Ana Dili Eğitimi Dergisi, 1(2), 55-74.

Ana Dili Eğitimi Dergisi
Journal of Mother Tongue
Education
ADED - JOMTE
www.anadiliegitimi.com

\title{
Türkçe Öğretiminde Eleştirel Düşünmeyi Geliştirme Bakımından Ömer Seyfettin'in Hikâyelerinin Yeri
}

Keziban Tekşan*

\section{Özet}

Ömer Seyfettin'in hikâyelerinin eleştirel düşünmenin özellikleri açısından incelenmesi ve bu hikâyelerin Türkçe öğretiminde nasıl kullanılabileceğinin tespit edilmesi araştırmanın amacını oluşturmaktadır. Tarama modelinde betimsel bir çalışma olan araştırmada nitel veri toplama teknikleri kullanılmıştır. Alan taraması yoluyla eleştirel düşüncenin özellikleri belirlenmiş, Ömer Seyfettin'in bütün hikâyeleri bu özelliklere göre değerlendirilerek veriler elde edilmiştir. Araştırmanın sonucuna göre Ömer Seyfettin'in hikâyelerinin eleştirel düşünmenin özelliklerini büyük ölçüde taşıdığı tespit edilmiştir. Buna göre Ömer Seyfettin'in hikâyeleri, eleştirel düşünmeyi geliştirme bakımından Türkçe öğretiminde kullanılabilecek zengin metinlerdir.

Anahtar Kelimeler: Türkçe Dersi, Ömer Seyfettin'in Hikâyeleri, Eleştirel Düşünce.

\section{Stories of Ömer Seyfettin in Terms of Improving Critical Thinking in Turkish Language Education}

\begin{abstract}
This study aims at analyzing the stories of Omer Seyfettin in terms of characteristics of critical thinking and determining how these stories can be used in Turkish Language Education. This is a descriptive study in survey model and qualitative data collection methods were used. Characteristics of critical thinking were determined based on a review of literature and data were obtained by evaluating all of the stories according to these characteristics. At the end of research, it was found that the stories of Omer Seyfettin substantially have the characteristics of critical thinking. Accordingly, these stories of Omer Seyfettin are rich texts to be used in Turkish Language Education with respect to improving critical thinking.
\end{abstract}

Key Words: Turkish Course, the Stories of Omer Seyfettin, Critical Thinking.

* Yrd. Doç. Dr. Çanakkale Onsekiz Mart Üniversitesi Eğitim Fakültesi, E-posta:

kezbanteksan@comu.edu.tr 


\section{Giriş}

Hızla gelişen bilgi teknolojileri bilginin hem artmasını hem çeşitlenmesini hem de ona kolay ulaşılmayı sağlamıştır. Artık toplumların hedefi vatandaşlarını hızı teknolojik değişiklikleri takip edebilecek ve ona uyum sağlayabilecek becerilerle donatmaktır. Bugünün insanı sunulan bilgileri ayıklamak ve seçimler yapmak zorundadır (Şahinel, 2001:36). İyi yetiştirilmiş insan gücü hem toplumların hem de kalkınmanın en önemli girdisi olarak kabul edilmekte ve eğitim sistemleri buna göre düzenlenmektedir (Tural, 1988:1). Yeni eğitim anlayışının temel hedeflerinden biri eleştirel düşünme becerilerine sahip bireyler yetiştirmektir. Eleştirel düşünme düzeyleri yüksek olan bireyler, eğitimin beklenen sonuçlarından birisi olarak kabul edilmektedir (Semerci, 2000; Korkmaz, 2009; Kökdemir,2003). "Günümüz eğitim kurumlarının önemi, eğitimin yaşam boyunca devam etmeye başlamasıyla birlikte artmaya başlamıştır. Öte yandan çağdaş dünyanın gereksinimleri günümüz bireylerinin düşünme becerilerine sahip olmalarını bir zorunluluk haline getirmiştir. Öğretimde bilgi alıp verme yerine, düşünmeyi öğrenme önem kazanmaktadır. Bu yüzden modern okullarda düşünen, eleştiren, üreten, bilgiye ulaşma yollarını bilen bireyler yetiştirilmeye çalışılmakta, öğrencilere düşünme becerilerini kazandırmaya yönelik eğitim programları hazırlanmaktadır" (Seferoğlu ve Akbıyık, 2006:193).

Bu sebeple üst düzey düşünme becerilerinden biri olarak kabul edilen eleştirel düşünme, farklı derslerin öğretim programlarının önemli hedefleri arasına girmiş ve bu hedefe uygun olarak öğrenme ve öğretme ortamları düzenlenmiştir. 2005-2006 eğitim öğretim yılında ülke genelinde uygulanmaya başlanan yeni ilköğretim programları ile öğrencilere (sekiz) temel becerilerin kazandırılması hedeflenmiş ve bu beceriler bütün derslerin programlarında yer almıştır. Bu beceriler Türkçeyi doğru, güzel ve etkili kullanma, eleştirel düşünme, yaratıcı düşünme, iletişim kurma, problem çözme, araştırma, karar verme, bilgi teknolojilerini kullanma ve girişimcilik becerileri olarak belirlenmiştir (Millî Eğitim Bakanlığı (MEB), 2006).

Türkçe dersinde bu temel becerilerden özellikle eleştirel düşünme becerisine programın diğer bölümlerinde de çokça yer verilmiştir. Eleştirel düşünme, eleştirel bakış açısı kazandırmak Türkçe dersinin genel amaçları içerisindedir. "Yapıcı, yaratıcı, akılcı, eleştirel ve doğru düşünme yollarını öğrenmeleri, bunları bir alışkanlık hâline getirmeleri, bilgiye ulaşmada kitle iletişim araçlarından yararlanmaları, bu araçlardan gelen mesajlara karşı eleştirel bakış açısı kazanmaları ve seçici olmaları" (MEB, 2006:4).

Programdaki Temel Yaklaşım başlığı altında da eleştirel düşünme becerisine vurgu yapılmıştır. "Dinlediklerini, izlediklerini ve okuduklarını anlayan; duygu, düşünce ve hayallerini anlatan; eleştirel ve yaratıcı düşünen, sorumluluk üstlenen, girişimci, çevresiyle uyumlu, olay, durum ve bilgileri kendi birikimlerinden hareketle araştırma, sorgulama, eleştirme ve yorumlamayı alışkanlık hâline getiren, estetik zevk kazanmış ve millî değerlere duyarlı bireyler yetiştirilmesi amaçlanmıştır" (MEB, 2006:3).

Programın temel dil becerisi amaç ve kazanımlar bölümünde dinleme becerileriyle ilgili kazanımların pek çoğu öğrencilere eleştirel düşünme becerisi kazandırmaya yöneliktir. "Dinlediklerinde/izlediklerinde sebep- sonuç ilişkilerini belirler. Dinlediklerinde/izlediklerinde amaç-sonuç ilişkilerini belirler. Dinlediklerindeki/izlediklerindeki örtülü anlamları bulur. Dinlediklerinde/izlediklerinde yer alan öznel ve nesnel yargıları ayırt eder. Dinlediklerine/izlediklerine ilişkin karşılaştırmalar yapar. Dinlediklerini/izlediklerini kendi hayatı ve günlük hayatla karşılaştııı (MEB, 2006:16-17). Aynı kazanımlar okuma 
becerisinde okunan metinler için de belirtilmiştir. "Metindeki sebep-sonuç ilişkilerini fark eder. Metindeki amaç-sonuç ilişkilerini fark eder gibi (MEB, 2006:27-28).

Temel dil becerilerinin kazanımına yönelik önerilen yöntem ve teknikler arasında her dil becerisiyle ilgili eleştirel düşünme becerisine yönelik yöntem ve tekniğe yer verilmiştir. Eleştirel Dinleme/ İzleme, Eleştirel Konuşma, Eleştirel Yazma, Eleştirel Okuma.

Yeni Türkçe Öğretim Programının en önemli yeniliklerinden biri de ölçme ve değerlendirme bölümünde yer alan Öz Değerlendirme, Akran Değerlendirme gibi ölçme araçlarının geliştirilmesidir. Bu araçlarla "Öğrencilere eleştirel bakış açısı kazandırmakta ve yapılan herhangi bir çalışmayı ölçütlere göre değerlendirebilme becerisinin kazanmasında etkili olmaktadır" (MEB, 2006:231) amacı güdülmüştür.

Üst düzey düşünme becerileri gerektiren eleştirel düşünme için öncelikle bireyin düşünme becerisine sahip olması gerekir. Düşünme becerisi Türkçe dersinde kazandırılmaya çalışılan temel dil becerileriyle birlikte öğretilir. "Eleştirel düşünebilmek için gerekli bilişsel ve duyuşsal becerilerin tamamı çocuklarda okuma ve dinleme kapasiteleri aracılığıyla zaman içinde köklü bir biçimde geliştirilmelidir (Akınoğlu, 2001:16). Birey okuyarak ve dinleyerek çevresini öğrenmeye çalışırken aynı zamanda düşünme faaliyetini de gerçekleştirir. Çünkü dil, bireyin hem bilgilerin öğrenilmesinde hem de öğrenilen bilgilerin ifade edilmesinde kullandığı en önemli araçtır. "Bulgular dil ve düşüncenin birbirleri ile etkileşim içinde, birbirlerinin gelişimlerini etkiledikleri ve dili düşünceden, düşünceyi dilden bağımsız düşünmenin olası olmadığı sonucunu desteklemektedir (Sezer, 1993:103). Bireyin sahip olduğu dil becerisi ile düşünme becerileri arasında doğrudan bir ilişki vardır ve ana dil öğretiminin düşüncenin de öğretimi olduğunu söylemek mümkündür (Yalçın, 2002). Dolayısıyla düşünce eğitiminin en etkin bir şekilde Türkçe dersinde kazandırılabileceği söylenebilir.

Türkçe dersi etkinlikleri metinler aracılığıyla yapılır. Programda metinlerde bulunması gereken özellikler belirtilirken "Metinler, öğrenciye eleştirel bir bakış açısı kazandıracak özellikler taşımalıdır" (MEB, 2006:56) maddesi eleştirel düşünmeye verilen önemi yansıtmaktadır. Edebî metinler dilin ve düşüncenin en etkili anlatıldığı metinler olduğundan bu metinlere eleştirel bir bakış açısıyla yaklaşmak, eleştirel düşünmeyi öğrenmede etkili olabilir. Battal (2010: 179) da öğrencilere okuma alışkanlığı kazandırılarak farklı eserler üzerinde düşünmeleri, eserleri analiz ederek çelişkileri, ön yargıları, yazarın referans noktalarını, eğilimleri bulmaları sağlanarak eleştirel düşüncenin öğretilmesini önerir. "Metinlerin yapısındaki farklııklar eleştirel değerlendirme sürecini kaçınılmaz kılar" diyen Karadüz (2010:1579) ise "Metin incelemelerinde sorgulama, karşılaştırma, değiştirme ve değerlendirme yaklaşımlarına yer verildiğinde öğrenciler eleştirel düşünebilmeyi öğrenirler “ tespitinde bulunur. "Kurgulayıcı bir metinde yazar, yaşadığımız dünyanın kişilerini, nesnelerini, durumlarını, olaylarını, ilişkilerini gereç olarak kullanır. Metni okuyan ya da dinleyen kişi ise eserde yer alan gereçleri düşünme becerilerini kullanarak tanımaya, sorgulamaya, nasıl bir araya getirildiklerini anlamaya çalışır. Eserde var olan kurgusal dünyayla kendi gerçekliği arasında ilişkiler kurarak anlamlar elde eder. Böyle bir sürecin varlı̆̆ı, eleştirel düşünmenin gelişmesini destekler" (Adalı, 2004:223). Okumayı, "Okuyucu ve yazar arasında uygun bir ortamda gerçekleşen görüş alışverişi” olarak kabul eden Akyol da "Bu süreçte okuyucu, metni anlamaya uğraşmakta ve anladıklarıyla ön bilgilerini birleştirerek yeni anlamlar ortaya koymaya çalışmaktadır" (Akyol, 2007: 15) derken eleştirel düşünmenin anlama ve çıkarımda bulunma becerilerine vurgu yapmaktadır. Dolayısıyla Türkçe öğretiminin temel 
materyali olan metinler iyi seçilmeli ve bu anlayışla okunup yorumlanmalıdır. Böylece öğrenciler, metinler üzerinde düşünüp yeni anlamlar elde ederek eleştirel düşünme becerisine ulaşabilirler.

Türkçe dersinde metin seçiminde akla gelecek ilk isimlerden bir Ömer Seyfettin ve onun hikâyeleri olmalıdır çünkü “Ömer Seyfettin'in edebiyatımıza küçük hikâye nev'inde en başarılı örnekleri kazandıran sanatkârlarımızdan olduğu yarım asırı epey aşan zamandan bu yana yerleşmiş bir hükümdür; bu yolda eriştiği haklı ün dolayısıyla hikâyelerinin hemen hepsi külliyat halinde birçok defa basılmakla beraber, bu nevi dışındaki yazıları üzerinde esaslı bir inceleme yapılmamış, bunlar muhtelif gazete ve dergilerde, başkaca kaynaklarda dağınık olarak kalmıştıı" (Tansel, 1985:55). Onun hikaye yazma tekniğini çok iyi bildiğini belirten Enginün ise bu özelliklerin devrin başka şahsiyetleri tarafından da paylaşıldığını belirtir. " Fakat Ömer Seyfettin onlar arasında yeganedir" (Enginün, 1985:47) der.

Ayrıca, "Ömer Seyfettin, çevre tasvirlerinden ve ruhsal çözümlemelerden çok olaya önem verir, edebiyat aracılığıyla sosyal sorunlara eğilir, toplumun her kesiminden insanı ele alarak, yaşanan olumsuzluklardan bir ders çıkarma eğilimi taşır(...)Çocukların hikâyenin bütününden ya da hikâyelerdeki kahramanların/kişilerin konuşmalarından, yapıp-etmelerinden hareketle kendilerine dersler çıkarmasını öngörür" (Şimşek, 2008:141-142). O, birçok hikâyesinde eğitici özelliklere yer vererek bilhassa kişilerin ve kurumların olumsuzluklarını biraz da mizah ile süsleyerek eleştirme yoluna giderek toplumu uyarma görevi görmüştür. Dolayısıyla Türkçe dersinde Ömer Seyfettin'in hikâyeleri kullanılabilir.

Geçgel (2007), Ömer Seyfettin'in hikâyelerini Türkçe dersi dışındaki dersler açısından da önemli görür ve "Onun hikâyeleri konu ve tema özellikleri yönüyle; Türkçe, Sosyal Bilgiler, Vatandaşlık ve İnsan Hakları Eğitimi, T.C. İnkılâp Tarihi ve Atatürkçülük gibi derslerin etkinliklerinde kullanılabilecek nitelikte eğitim-öğretim materyali olma özelliğine de sahiptir"değerlendirmesini yapar.

Kırıkkale ilindeki resmi ilköğretim okullarında yapılan bir araştırmada öğrencilerin Ömer Seyfettin'i hikâyeci olarak tanıyıp tanımadıklarına yönelik sorulan sorulara verdikleri cevaplar öğrencilerin Ömer Seyfettin'i tanıyıp okuduklarını göstermiştir. Araştırmaya göre öğrencilerin hemen hepsi $(\% 94,4)$ Ömer Seyfettin'i ilköğretimin birinci kademesinde tanımaya başlamışlardır. Araştırmada "Ömer Seyfettin 'in hikâyelerinin sevilerek, beğenilerek okuduğunu; yazarın yarattığı kahramanlardan ve işlediği konulardan öğrencilerin etkilendiğini, yazarın dil ve anlatımının da hikâyeleri beğenerek ve severek okumada etkili olduğunu göstermektedir" (Tosunoğlu, Haktanır, Çocuk, Gök,2008:187) sonucuna ulaşılmıştır.

\section{Eleştirel Düşünce}

Eleştirel düşünce, felsefe, psikoloji ve eğitim gibi bilimlerinin inceleme alanına giren üzerinde önemle durulan bir kavramdır. Bu kavramın tanımı, "Bireyin ne yapacağına ve neye inanacağına karar vermesi için çözümleyici, değerlendirmeye yönelik bilinçli yargılarda bulunması ve bu yargıları ifade etmesi" (Evancho, 2000'den aktaran Seferoğlu ve Akbıyık, 2006: 195) şeklinde disiplinler arası bir bakışla tanımla yapılmıştır. Akınoğlu (2001) ise kaynaklardaki tanımları inceleyerek anahtar öğelerden hareketle bir tanım yapar. "Bilgi edinme sürecinde, irdeleyebilmeyi, çok yönlü sorgulayabilmeyi gerektiren düşünme süreçlerini etkili, tarafsız ve disiplinli bir şekilde uygulayabilmeyi, yeni durum ve ürünleri kriterlere dayalı değerlendirmeyi ve geliştirmeyi içeren zihinsel ve duyuşsal bir süreç olarak tanımlanabilir." 
Mevcut bilgiyi sorgulama, bilginin altında yatan sebepleri bulma ve birçok bakış açısını değerlendirebilmek için eleştirel düşünme becerisine sahip olmak gerekir. Böylece başkalarının veya kendimizin iddia ya da fikirlerini tarafsız ve önyargısız bir şekilde değerlendirebiliriz. Bu değerlendirme gelişi güzel yapılmaz. Birey, belli ölçütlere göre elde ettiği bilgiyi sorgulayarak, değerlendirip bir yargıya varır (Semerci, 1999: 12). Denilebilir ki "Eleştirel düşünme, ayrıca, ölçüt kullanan bir düşünmedir de" (Lipman, 2003'ten aktaran Tok, 2008). Bu da değerlendirmeyi kişisellikten kurtarır, bir yönteme dayandırır. Eleştirel düşünmenin en önemli özelliği de budur. Kazancı (1985:41) da tanımında buna vurgu yaparak eleştirel düşünmeyi, "Bir problem durumunu bilimsel, kültürel ve sosyal standart ölçülere göre tutarlılık ve geçerlilik bakımından yargılama ve değerlendirmede işe koşulan tavır, bilgi ve beceri süreçlerinin bütünüdür" şeklinde tanımlamaktadır.

Düşünmenin en gelişmiş ve en ileri biçimi olarak kabul edilen eleştirel düşünme, seçme, ayırma becerilerini gerektirir. Çünkü eleştirel düşünme sayesinde nitelikliyi niteliksizden, doğruyu yanlıştan ayırt edebiliriz. Seçme, ayırma, karar verme sürecinin başlangıcıdır. Bu yüzden eleştirel düşünme karar verme süreci olarak da görülmektedir. Eleştirel düşünme, "Ne yapılacağına, neye inanılacağına karar vermeye odaklanmış yansıtıcı ve mantıkı düşünme" (Ennis 1985'ten aktaran Özcan, 2007:20) dir. Bu bakımdan eleştirel düşünce "Problem çözme olarak sonuca ulaşmada kullanılan kriterleri, alternatifleri tanıma ve seçme olarak tanımlanabilir" (Özden, 1999:114). "Bazı eğitimcilere göre de eleştirel düşünme, problem çözme ile eş anlamlıdır" (Kazancı, 1985:42).

Eleştirel düşünce; analiz etme, fikirleri üretip düzenleme, fikirleri savunma, çıkarımlar yapma, iddiaları değerlendirme ve problem çözme gibi karmaşık becerilerinin bileşeni mantıklı ve yansıtıcı bir düşüncedir ve bireyin eleştirel düşünebilmesi için de belli eğilim ve tutumlara sahip olması beklenir (Özdemir, 2005:28). Çünkü bireyin eleştirel düşünceye eğilimi yoksa ondan eleştirel düşünmesi beklenemez. "Bu eğilim, onun eleştirel düşünme kapasitesini önemli ölçüde etkilemektedir" (Yalın, Şensoy,2011:525). Bireyin eleştirel düşünmeye olan arzusunu yansıtan eleştirel düşünme eğilimi "Meraklı olma, açık görüşlü olma, sistematik olma, çözümleyici olma, entelektüel olgunluk, özgüven sahibi olma ve doğruyu arama" (Branch, 2000'den aktaran Seferoğlu ve Akbıyık, 2006:195) şeklinde sıralanmıştır. Ancak "Bireyin eleştirel düşünme eğilim ve tutumlarına sahip olması eleştirel düşünme becerilerini iyi bir şekilde kullanacağı anlamına gelmemektedir (Facione, 1990'dan aktaran Özdemir, 2005:27)

\section{Eleștirel Düşünme Becerileri}

Eleştirel düşünme becerilerinin neler olduğu konusunda kaynaklarda çok çeşitlilik vardır. Bu konuda çalışan birçok eğitimci, eleştirel düşünmeyi oluşturan beceriler hakkında listeler ve sınıflamalarda bulunmuştur.

Watson ve Glaser (1964) sorunu tanıma, sorunun çözümü için uygun bilgileri toplama ve seçme, yapılandırılmış ve yapılandırılmamış varsayımları tanıma, ilgili sonuca götüren varsayımları seçme ve formüle etme, geçerli sonuçları çıkarma ve çıkarsamaların yeterliliğini tartışma (Wilson ve Wagner, 1981'den aktaran Tok, 47) olarak belirlemişlerdir. Özden (1999:112) de, eleştirel düşünme becerilerinin belirleyici özelliklerini:

“Önyargı ve tutarlılığı değerlendirme, birinci el ve ikinci el kaynakları ayırt etme, çıkarsamaları ve nedenlerini değerlendirebilme, varsayımları, fikirleri ve 
iddiaları ayırt etme, argümanın eksik taraflarını ve açıklamalardaki belirsizleri görme, tanımlamaların yeterliliğini ve sonuçların uygunluğunu ölçme" şeklinde sıralamıştır.

Hederson ve Decaroli ise tanımlama, denence kurma, bilgi toplama, yorumlama, akıl yürütme, değerlendirme, uygulama olmak üzere yedi tür birbirini tamamlayan beceriden söz eder (Kazancı, 1989:43-44).

Bazı bilim adamları da eleştirel düşünme becerilerini duyuşsal stratejiler, bilişsel stratejiler makro yetenekler ve bilişsel stratejiler mikro beceriler olmak üzere üç temel yapıda gruplandırıp otuz beş farklı boyutta incelemişlerdir (Paul, Binker, Jensen ve Kreklau 1990'dan aktaran Akınoğlu, 2007:30, aktaran Şahinel, 2002:9-19)

Potts ise eleştirel düşünme becerilerini "bilgiler arasındaki ilişkileri ve benzerlikleri bulmak; problemleri planlamak ve bu problemleri çözmek için kullanılan bilgilerin geçerliliğini ve uygunluğunu belirlemek ve problemlere yaklaşım yollarını ve çözümleri bulma ve değerlendirme" (Potts, 1994'ten aktaran Kürüm, 2002:28) olarak en kısa şekilde açıklamıştır.

Delphi raporunda ise eleştirel düşünme becerileri; anlama, analiz, değerlendirme, çıkarımda bulunma, açıklama ve kendini düzenleme olarak tanımlanmakla beraber değerlendirme, analiz ve çıkarımda bulunma çekirdek beceriler diye kabul edilmiştir (Facione, 1990'dan akt. Özdemir,2005:31).

Eleştirel düşünme becerilerinin bilgilendirme ve öğretim amaçlı olarak, yapay bir şekilde bölümlendirilmiş ve sınıflandırılmış olduğunu açıklayan Gündoğdu (2009:64) bu becerilerin gerçek hayatta birbirinden bu kadar kolayca ayrılamayacağını, eleştirel düşünmenin bu becerilerin bir bütün olarak ve birbirine eklemlenerek kullanılan bir düşünme olduğunu bildirir.

\section{Yöntem}

Araştırmada betimsel analiz yöntemi kullanılmıştır (Karasar, 2009). Öncelikle alanla ilgili kaynaklar taranarak eleştirel düşünmenin özellikleri tespit edilmiştir. Çalışmada, Delphi raporunda (Facione, 1990'dan aktaran Özdemir, 31) belirtilen anlama, analiz, değerlendirme, çıkarımda bulunma, açıklama ve kendini düzenleme diye tespit edilen eleştirel düşünme becerileri esas alınmış;bu özelliklere göre de Ömer Seyfettin'in bütün hikâyeleri değerlendirilmiştir.

Ömer Seyfettin'in bütün hikâyeleri farklı yayınevleri tarafında farklı isimlerle yayınlanmıştır. Bilim çevrelerinde en çok kabul gören Hülya Argunşah'ın hazırladığı Dergâh yayınları tarafından yayınlanan Ömer Seyfettin Bütün Eserleri (Hikâyeler 1 - 4) adlı eserdeki yüz kırk altı hikâye, çalışmanın temel verilerini oluşturmuştur. Eleştirel düşünme, eleştirel bakış açısı kazandırmak, Türkçe dersinin genel amaçları içerisinde yer almakta ve Türkçe dersi metinlerle yürütülmektedir. Dolayısıyla bu çalışmada Ömer Seyfettin'in hikâyelerinin bu amacı gerçekleştirmede kullanılabilirliği sorgulanarak, onun hikâyelerinde eleştirel düşünmenin örnekleri ne kadar vardır ve bu hikâyeler Türkçe dersinde nasıl kullanılmalıdır sorusuna cevap aranmıştır.

\section{Bulgular ve Yorum}

Tarih Ezelî Bir Tekerrürdür, Bahar ve Kelebekler, Pamuk İpliği, Primo Türk Çocuğu(Nasıl doğdu?), Hürriyet Bayrakları, Primo Türk Çocuğu (Nasıl öldü?), Sivrisinek, Çanakkale'den Sonra, Pembe İncili Kaftan, Mermer Tezgâh, Fon Sadriştayn'ın Oğlu, Tuhaf Bir Zulüm, illk Düşen Ak, Pireler, Baharın Tesiri, Perili Köşk, Niçin Zengin Olmamış, Ezeli Bir Roman, Memlekete Mektup, Kurbağa Duası ve İnat hikâyelerinde eleştirel düşünmenin özellikleri tespit edilmiştir. Ulaşılan bulgular, aşağıda hikâyelerden örneklerle belirtilmiştir. 


\section{Anlama}

Tanımlama diye de adlandırılır. Eleştirel düşünmenin ilk adımı problemi ya da ileri sürülen fikri belirleme ve onu tarafsız bir şekilde tanımlamakla başlar. Bunun için tecrübelerden, olaylardan, yargı ve inançlardan faydalanılır. Tecrübe, olay, veri, yargı inanç, kurallar, işlemler ve ölçütleri anlamak ve anlamları ile önemlerini görebilmek anlama becerisi gerektirir.

Ömer Seyfettin'in pek çok hikâyesinde de eleştirel düşünmenin bu özelliği görülür. Kurbağa Duası, İnat, Perili Köşk, Illk Düşen Ak, Mermer Tezgâh gibi hikâyelerde, hikâye kahramanları öncelikle problemi anlamaya, iddiayı etraflıca irdeleyerek tanımaya çalışmışlardır. Mesela Perili Köşk hikâyesinin kahramanı Sermet Bey, çok beğendiği köşkü kiralamak isteyince bekçinin "-Burada oturamazsınız efendim..." cevabını hemen kabullenmez sorgular çünkü o, tam bir eleştirel düşünme becerisine sahiptir. "Sermet Bey, gözüyle gördüğüne, kulağıyla işittiğine inananlardan değildi. Eliyle sıkı sıkıya tutup hissetmeyince bir şeyin varlığına hükmetmezdi" (Seyfettin, 1999c:215). Bu yüzden "-Perinin bize zararı dokunmaz diyerek" köşkü kiralar. Yine Mermer Tezgâh hikâyesinde "Yegâne merakı "dünyanın ahvalini" tetkikti" diye tanıtılan hikâyenin kahramanı Cabi Efendi, bir gün sokaktan geçerken bir marangoz dükkânı ve içinde mermer tezgâh görünce şaşırdı "Hiç mermerden doğramacı, marangoz tezgâhı olur muydu? Olursa... Mutlaka bunun hususî bir sebebi vardır!" diyerek işin aslını anlamaya çalışır. Bunun için marangozu soru yağmuruna tutar. Uzun sorgulamadan sonra da mermer tezgâh kullandığı halde bir kere bile keserini yanlış vurmayan marangozun sırrını anlar ve bunu şöyle belirtir:

“- Oğlum, bu senin elindeki maharetinden değil! Dedi

- Ya neden?

Düşüncesizliğinden...

Düşüncesizliğimden mi?

-Evet."

Yazarın en bilinen ve sevilen tarihi konuyu ele aldığı hikâyelerinden biri de "Pembe İncili Kaftan"dır. Hikâyede İran ile olan sorun çok iyi anlaşılmış sorun çok iyi tespit edilmiştir. "-Cesur bir adam lazım, paşalar... dedi, biz onun sırmalara, altınlara, elmaslara gark ederek gönderdiği elçisine padişahımızın elini öptürmedik, ancak dizini öpmesine müsaade ettik. Şüphesiz o da mukabele etmeğe kalkacak" (Seyfettin, 1999c, 124) diyen sadrazamın fikrine Kubbealtı vezirleri de katılırlar.

Kurbağa Duası hikâyesinde ise bir arkadaş topluluğunun bir kır eğlencesinde kurbağaların çıkardığı sesten rahatsız olması üzerine Bahir Hoca'nın kurbağalara nefes ederek onları susturmasını bir türlü kabul etmeyen anlatıcı yazar bu olayın aslını öğrenmek, anlamak için uğraşır. Bunun için Bahir Hoca'ya ilmi pusu kuran yazar konuşma sırasında "Hayvanlarda ruh olmadığını, mahlûkattın maneviyat haricinde tıpkı nebat gibi yaşadıklarını anlatıyordum." diyince Hoca da aynı fikirde olduğunu söyleyince yazar yalan söylediğini çünkü onun kurbağalara nefes ettiğini bunun için "hayvanların maneviyat haricinde yaşadıklarını bilmediğini" söyler. Bunun üzerine Bahir Hoca "-Ben kurbağalara nefes etmedim" diyerek işin aslını -nargilesinin marpucunu havuza sarkıttığını kurbağaların da onu yılan sanıp kaçtıklarını -anlatır (Seyfettin, 1999ç,106). Böylece yazar işin aslını anlamış olur. 


\section{Analiz}

Bilginin ya da iddianın parçalara ayrılması ve bunlar arasındaki ilişkilerin belirlenme aşamasıdır. Bütünü ögelere ayırma becerisi diye de tanımlanır (Özden, 1999:104). Bloom'un Taksonomi 'sinde belirttiği altı düşünme şekillerinden birini oluşturmaktadır. Bilgi veya iddianın en ince detayına kadar incelendiği, sebep sonuç ilişkisinin belirlendiği aşamadır. Birey bütünü parçalara ayırırken aynı zamanda bütünün nasıl oluştuğunu da fark edebilecektir. "Analiz becerisi bireylerin bir şeyin düzenlenme şablonlarını fark etme, nesneleri ortak özelliklerine göre sınıflandırabilme, hipotez, sav ve kişisel inançları tanımlayabilme, bir bilgi yığınının ana fikrini tanımlayabilme ve ana fikri yan fikirlerden ayırabilme, düzenlenmiş bilgideki ardışıklığı ve hiyerarşiyi bulabilme gücü ve yeteneğidir" (Özdemir, 2005:34).

Ömer Seyfettin, hikâyelerinde bir iddiayı ispatlamak için o konuyla ilgili en küçük ayrıntıya bile yer verir, sebep sonuç ilişkisini inceler. Mesela Hürriyet Bayrakları hikâyesinde iki askerin konuşması buna güzel bir örnektir:

-Hem bu nasıl millî bayram? Hangi milletin bayramı?

-Osmanlı milletinin..

-Osmanlı demekle Türkleri mi kastediyorsunuz?

-Hayır, asla... Bütün Osmanlıları...

-Bütün Osmanlılar kimler?

-Tuhaf sual!

Araplar, Arnavutlar, Rumlar, Bulgarlar, Sırplar; Ulahlar, Yahudiler, Ermeniler, Türkler... Hâsılı hepsi...

-Bunlar demek bir millet?

-Şüphesiz...

-Fakat ben şüpheleniyorum.

-Niçin?

-Söyleyiniz Ermeniler bir millet değil mi?

-Biraz durdu tereddütle cevap verdi:

-Evet bir millettir.

-Arnavutlar da bir millet?

-Arnavutlar da (Seyfettin, 1999a, 232) "Bu konuşmanın devamında asker karşısındaki askere hesap konusunu hatırlatarak "Ben size söyleyeyim. Tabiî inkâr edemeyeceksiniz. Bir cinsten olan şeyler cemolunabilir. Mesela on kestane, sekiz kestane, dokuz kestane! Hepsi yirmi yedi kestane eder, değil mi? (Seyfettin, 1999a, 233)" diye sorup evet cevabını alınca yine ona şu değerlendirmeyi yapar: Ve bu imkânsızlık nasıl riyazî ve bozulmaz bir kaide ise birbirinden tarihleri, an'aneleri, meyilleri, müesseseleri, lisanları ve mefkûreleri ayrı milletleri cemedip hepsinden bir millet yaratmak da o kadar imkânsızdır (Seyfettin, 1999a,233)" "-Bir cinsten olmayan şeyler cemedilemez. Mesela on kestane, sekiz armut, dokuz elma... Nasıl cemedeceksiniz. Bu mümkün değildir". 
Bahar ve Kelebekler hikâyesinde de bir büyükanneyle genç torunu arasında geçen karşılıklı konuşmalarda geçmişin kadını ile günün kadını karşılaştırıır. Genç torun mutsuzdur büyükanne bunun sebeplerini kendi gençlik zamanı ile karşılaştırarak anlatmaya çalışır. Büyükanneye göre onların aldıkları kültür, gelenek ve görenekler hep mutluluk verici şeylerdir. Bunu "Her şey bizim için zevk ve eğlence idi, her şey! Çocukluk, mektebe başlayış, feraceye giriş, kocaya varış, doğuruş, hatta intiyarlayıs bile... Bunların hep ayinleri vardı. Her kadının bu devirleri diğer birçok kadınlar için zevk, bir eğlence vesilesi olurdu. Bütün hayatımız eğlence içerisinde geçerdi" (Seyfettin, 1999a, 120) diye anlatır. Büyükanneye göre genç neslin mutsuz olmasının sebebi ise aldıkları Batılı eğitim ve öğrenimdir (Önertoy, 1985:79). "Şimdi siz Frenk mürebbiyeler elinde büyüyor, kendi lisanınızın güzelliklerini tanımıyor; başka memleketleri, başka şeylerini öğreniyorsunuz. Onlara benzemek istedikçe kendi benliğinizden uzaklaşıyor, etrafınızdan nefret ediyor, hakikaten sevinç ve saadetten mahrum kalıyorsunuz" (Seyfettin, 1999a, 118) diyen büyükannenin bir başka tespiti de mutsuzluk sebeplerinden birinin de batıyı taklit etmektir. "Bugün Frenkçe okumak, mütemadiyen esvap değiştirmek, moda yapmak çılgınlıklarından, soğukluklarından, boş bir tekebbürden, manasız ve münasebetsiz bir tefevvuk iddiasından başka bir şey yoktu... Frenklik bir veba gibi içimize girmiş, yanaklarımızın allığını, dudaklarımızın tebessümünü silmiş, feracelerimizi parçalamış, pabuçlarımızı atmış, parmaklarımızı narın bir mercan gibi parlatarak güzelleştiren kınalarımızı bile ortadan kaldırmıştı. Eşyamızı, esvaplarımızı, evlerimizi değiştirirken ruhlarımızı da değiştirmişti. Her şey yalan, her şey sahte, her şey taklit oldu. An'a nelerimiz öldü. Saadet uzak bir hayale, yetişilmez bir hülyaya inkılâp etti... (Seyfettin, 1999a, 119)

Büyükanne şimdiki kadınların hayatlarını hapishaneden farksız görür. Onların zamanında kadınların erkeklerden ayrı ve çok geniş bir kadınlar âlemi vardır.

\section{Değerlendirme}

Değerlendirmede bireysel duygu ve tutumlar yoktur sadece belli ölçütler doğrultusunda ölçmek ve yargılamak vardır. Bunun için eleştirel düşüncede konuya uygun ölçüt geliştirmek esastır. Ölçüte göre değerlendirmenin yanında bilginin ya da iddianın güvenirliğini, kullanılabilirliğini de denetlemek gerekir. İdiaların güçlü ve zayıf yönlerini, konuyla ilgilerini belirleme gücüdür değerlendirme. Değerlendirmenin sağlıklı yapılabilmesi için varsayımlar, çıkarımlar, savlar, karşı savlar ve gerekçeler iyi değerlendirilip sonuca varılıp varılmayacağına karar verilmesi gerekir.

Ömer Seyfettin'in hikâyelerinde eleştirel düşüncenin en temel özelliği olan değerlendirmeye çokça yer verdiği görülür. Mesela Inat hikâyesinde yine yazar anlatıcı kahraman olarak karşımıza çıkar. Yazar, bir hikâyesindeki "atlar nemli çimenleri otluyordu" ifadesini yanlış bulan ve "Çimen otlanmaz, çayır otlanır" diye eleştiren Efruz Bey'in iddiasını belli ölçütlere göre değerlendirir. İlk olarak Merhum Cevdet Paşa'nın yöntemine başvurur. "Ben ne vakit lisana dair bir müşküle rast gelsem, hemen merhum Cevdet Paşa'nın "Millî Akademi” usulüne müracaat ederim. Malum ya, Paşa meşhur Kavaidi'ni yazarken evine birçok cahilleri toplar, fiilleri onlara tasnif ettirir, edatları onlara tekrarlattırırmış" (Seyfettin, 1999ç, 305) diyen yazar da aynı şekilde ev halkını çağııır, onlara sırayla aynı soruyu sorar"- Gözünün önüne bir çayır getir. Bu çayıra bir sürü at bıraksınlar... Bu aç atlar ne yaparlar?" (Seyfettin, 1999ç, 306) sorusunu sorar ve hepsinden çimenleri otlarlar cevabını alır. Bununla da yetinmeyen yazar, Efruz Bey'i görmeye gider ve onun iddiasının dayanaklarını değerlendirmeye çalışır. Bu sırada pencereden çimenleri otlayan keçileri görür ve Efruz Bey'e gösterir. 
Tuhaf Bir Zulüm hikâyesinde ise Türkleri çok iyi tanıyan eski bir Bulgar diplomatın Türkler hakkındaki değerlendirmeleri anlatılır. Gençliğinde İstanbul'da okuyan ve çok iyi Türkçe konuşan diplomat Türkler hakkındaki değerlendirmesini şu sözlerle ifade eder:

“-Türklerde hiç bir şey, hiçbir fikir, hiçbir ideal yoktur. Yalnız bir şey vardır.

Dedi. İkimiz birden sorduk:

$-\mathrm{Ne}$ ?

-Taassup!" (Seyfettin, 1999c, 38) Bu değerlendirmesini, iddiasını da yaşadığı deneyimlerini örneklendirerek anlatır. Diplomat vaktiyle Deliorman kaymakamlığı yaptığı sıralarda orada bir tane bile Bulgar olmadığını, Türkleri oradan uzaklaştırmak için Makedonya'dan bir aile getirterek onlardan domuz bulundurmalarını ve domuzlarını aç bırakmalarını ister. Türkler domuzlardan rahatsız oldukları için teker teker oradan kaçarlar ve iki sene içinde orada hiç Türk kalmaz. Diplomat bu durumu Türklerin domuza olan taassubu olarak değerlendirir.

Sivrisinek hikâyesi de yazarın değerlendirmelerde bulunduğu hikâyelerindendir. Hikâyede anlatıcı yazar Efzur Bey adındaki kahramanıyla ilgili değerlendirmelerde bulunur ve bunları örneklerle kanıtlama yoluna gider. Illk değerlendirmesi Efruz Bey'de liyakat olmadığını belirlemektir. Bunu ispatlamak için anlatıcı yazar şu değerlendirmede bulunur: "Liyakatin zıddı "aciz"dir. Kimde aciz varsa o şarlatandır, mütecavizdir. O asidir, ferdiyetçidir. Bir kelime ile söyleyeyim, "gayr-i-memnun"dur. Don Kişot gibi yel değirmenlerine meydan okur" (Seyfettin, 1999a, 330) der ve devamında "Ben sende liyakat olmadığını aczinden anlıyorum. Aczini de şarlatanlığından anlıyorum" (Seyfettin, 1999a, 330) değerlendirmesinde bulunur. Buna kanıt olarak da rüzgâr ve sivrisinek hikâyesini anlatır. Sivrisinek de rüzgârın karşısında haddini bilmeyerek rüzgârla eğlenmeye ona meydan okumaya başlamış. Rüzgâr "-ben rüzgârım, cirmim görünmez. Hızla estiğim, fırtına, bora, kasırga olduğum zamanlar en kuvvetli, en ağır şeyler karşımda çatır çatır yıkııı" demiş. Küstah Sivrisinek ise "-Puf puf, puf... Beni korkutamazsın. Ben de seni kızarsam bir yaparım, bir yaparım ki... (Seyfettin, 1999a, 331) diyerek meydan okur. Rüzgârın hızla esmesi sonucu korunmak için korkudan çatıya saklanan Sivrisinek, "-Ulan terbiyesiz rüzgâr! Ne oluyorsun? Yoksa bana bu fakirin çatısını mı söktüreceksin? (Seyfettin, 1999a, 332) diyerek şarlatanlığa devam eder. Anlatıcı yazar da "anlıyorsun ya... Rüzgâr yıkmayacak da, sözde sivrisinek o incecik ayaklarıyla koca çatıyı söküp atacak! Kıssadan hisse: Aciz daima şarlatan... İşte sevgili Efruz, senin manevi vaziyetin! (Seyfettin, 1999a, 332) değerlendirmesini yapar.

\section{4.Çıkarımda Bulunma}

Eldeki verilerden ve bulgulardan doğru tespitlerin yapılmasıdır çıkarım. Eğer doğru çıkarımlara ulaşılabilirse bu çıkarımlar yeni bilgilerin oluşmasına zemin hazırlayabilir. Bunun için yanlış çıkarımlarda bulunmamak en doğru ve kanıtlanabilir çıkarımlara ulaşmak gerekir. Bu sebeple çıkarsama "Bir sorunun tanımlanması, sorunun çözümü için uygun bilgiyi seçme" (Watson ve Glaser'den aktaran Kürüm, 2002) olarak tanımlanmaktadır.

Ömer Seyfettin'in hikâyelerinde eleştirel düşünme özelliklerinden çıkarımda bulunma da sıklıkla görülür. Mesela Pembe İncili Kaftan'da sadrazam ve Kubbealtı vezirleri İran elçisine karşı gösterdikleri davranışın aynısının kendi elçilerinin başına da geleceği çıkarımında bulunarak gerekli tedbiri alarak devletin onurunu çiğnetmeyecek bir elçi ararlar. "O halde bizden elçi gidecek adamın çok cesur olması lazım! Öyle bir adam ki ölümden korkmasın. Devletin şanına dokunacak hakarete karşı koysun. Ölüm 
korkusuyla, uğrayacağı hakaretlere boyun eğmesin..." (Seyfettin, 1999b, 124) Hikâyede elçi olarak Muhsin Çelebi'nin seçilmesi de tam bir çıkarım örneğidir. Bu görevi "-Mademki bu bir fedakârlıktır, fedakârlık ücretle olmaz. Hasbi olur. Devlete karşı ücretle yapılacak bir fedakârlık, ne olursa olsun, hakikatte şahsî bir kazançtan başka bir şey değildir. Ben maaş, mansıp, ücret falan istemem. Fahri olarak bu hizmeti görürüm" (Seyfettin, 1999b, 130) şartıyla kabul eden Muhsin Çelebi görevini lâyıkıyla yerine getirir. Muhsin Çelebi'nin Şahın sarayında, bütün malını mülkünü satarak aldığı ünlü Pembe İncili Kaftan'ı yere serip oturması da bir çıkarım örneğidir. Şahın sarayında onu küçük düşürmek isteyecekleri çıkarımını yapan Muhsin Çelebi, buna fırsat vermeden kaftanı yere sererek oturur ve yerdeki kaftanı almadan gider. Arkasından yetişip kaftanı getiren, unuttuğunu söyleyen muharibe "-Hayır unutmuyorum. Onu size bırakıyorum. Sarayınızda büyük bir padişah elçisini oturtacak seccadeniz, şilteniz yok... Hem bir Türk yere serdiği şeyi bir daha arkasına koymaz... Bunu bilmiyor musunuz?" (Seyfettin, 1999b, 133) cevabını verir.

Illk Düşen Ak hikâyesinde de “Bedbaht değilim. Mes’ut da değilim. Geçen sene müthiş surette canım sıkılmağa başlamıştı. Zayıflamıştım. "Nevrasteni oluyorum" şüphesi beni doktora götürdü" diyen otuz yaşındaki bir hastayı inceleyen doktor doğru çıkarımlarda bulunarak hastalığının adını koyar. Bu saadet hastalığıdır. Bu hastalıktan kurtulması için hastaya memuriyetinden ayrılmasını, böylece çalışmak zorunda kalacağını, boş durmayacağı için de canının sıkılmayacağını belirtir. Yine doktor sorgulaması sonucunda hastanın herhangi bir idealinin olmadığı çıkarımında da bulunur. "O halde hastalığınızın bir sebebi daha. Ne milliyetperverim diyorsunuz, ne de kozmopolit! Yani Araf'tasınız. Hâlbuki Araf insanlara mahsus değildir. Hayvanlar orada istirahat eder. Ama insan için ya cennet lâzımdır, ya cehennem!" (Seyfettin, 1999c, 345) diyerek hastasını bir ideal edinmeye yöneltir.

Pireler hikâyesi de doğru çıkarımlar yapılmıştır. Hikâyede evli bir çiftin çok sevdikleri köpekleri hastalanır, yemez içmez oynamaz sürekli yatar. Köpek İzmir'de ne kadar baytar varsa götürülür ama bir türlü iyileşemez. Bir arkadaşlarının"-Azizim, köpeğini kaybetmek istemezsen Avrupalı bir baytar bu, ona göster" (Seyfettin, 1999c, 309) önerisi üzerine köpeği Punto adında intiyar bir İtalyan baytara götürürler. Baytar “Titrek zayıf elleriyle Koton'u kucağımdan aldı. Gözlerine, ağzına baktı. Sonra tüyleri kokladı. Elleriyle beyaz tüyleri araladı. Dikkatli dikkatli baktı. Bunun üzerine bir avuç pire koy iyi olacak" (Seyfettin, 1999c, 310) deyince aile şaşırır. ilaç vermeyecek misiniz diye sorunca baytar "Bir avuç pire! Yıkamayacaksın. Üzerinde kalsın. Bu ilaçtır!" (Seyfettin, 1999c, 310) cevabını verir. Bunu bir türlü aklı kabul etmeyen hasta sahibi baytarla tartışır ve ona bunak diye hakaret eder. Baytar ise "-Haydi bire, kafasız adam, sen anlamaz bir şeyden. Git benim dediğimi yap. İyi olursa viziteyi getireceksin. İyi olmazsa yine geleceksin. Benim yüzüme "tüh" yapacaksın"(Seyfettin, 1999c, 311) diyerek meseleyi kapatır. Köpek sahibi baytarın dediklerini mantıklı bulmamakla beraber bir defa denemekten de geri duramaz. Köpeği, pirelerle dolu bir çuval deposuna koyarlar, bir gün sonra Koton'un canlandığını ayağa kalktığını, eskisi gibi sıçramağa başladığını görürler. Köpeği bir hafta yıkamazlar, o daha da canlanır, iştahı açılır. "Doktorun bu nasıl tesir ettiğini hâlâ anlayamadığımız tavsiyesini alay zannettiğime pişman oluyordum"(Seyfettin, 1999c, 312)diye hayıflanan köpek sahibi, baytara vizitesini götürür.

Ömer Seyfettin'in tarihî hikâyelerinde de pek çok doğru yapılan çıkarım örnekleri bulunur. Kütük, Vire, Topuz gibi hikâyelerde hem yaratıcı hem de doğru çıkarımlarla çok zor durumlardan başarıyla çıkan Türk askerinin başarısı anlatılır. 


\section{Açıklama}

Değerlendirmenin sonuca ulaştığı, varılan sonucun ifade edildiği, bu sonucun mantıklı iddialarla savunulduğu bölümdür.

Ömer Seyfettin'in hikâyelerinde ulaşılan sonucun ifade edildiği, iddiaların savunulduğu, kanıtların ispatlandığı bölümler de görülür. Mesela illk Düşen Ak hikâyesinde doktorun çıkarımlarına göre davranan hasta kısa sürede sağlığına kavuşur. "Bir "hiç" yıllarca yürüdüğümüz yolu değiştirebilir. Bana ideal sahibi olmamı tavsiye eden doktorun bu paradoksal sözleri çok tesir etti" (Seyfettin, 1999c, 346) diyen hasta "ideal hazır bir esvap gibi bulunup alınmayacağını" bildiği için milliyet cereyanı etrafında çıkan matbuatı okumaya başlayıp millî sanatı aramağa çalışır. Bursa'ya, Konya'ya seyahatler yapar ve sıhhatine kavuşur. "Getirdiğim kitaplar o kadar çoktu ki... Hatta yarısını okuyup bitiremedim. Ama sıhhatim yerine geldi. Artık kendimi düşünmez, dinleyemez oldum" (Seyfettin, 1999c, 346) diye çıkarımların ya da iddianın sonucunu açıklar.

Yine Perili Köşk hikâyesinde Sermet Bey, kiraladıkları köşkte her gece bir hayalin görünmesini perilere yoran ev halkına katılmaz. "Sermet Bey, atılan taşlara, kırılan camlara rağmen hâlâ periye inanmıyordu". Bunun için her zaman çamlığın içinde kaybolan periye dokunmayı düşünerek bir akşam çamlıktaki büyük bir çamın alt dallarından birine bindi ve perinin gelmesini bekledi. Peri gelince de onu yakalayıp köşke getirdi. "Köşk bahçe kapısına inmişti.-Insanmış, kerata! Ben dünyada ecinni falan yoktur, demez miyim? Hayal bir türlü beyaz çarşafı başından bırakmak istemiyordu. Sermet Bey zorla çekti. Sakalı bıyığına karışmış Hacı Niyazi Efendiyi görünce şaşırdılar" (Seyfettin, 1999c, 219)

Baharın Tesiri adılı hikâyede de iddianın sonucunu açıklama görülür. Hikâyenin kahramanı bahar mevsiminin güzelliklerinden etkilenerek her zamankinden erken kalkar ve bu güzelliği keşfetmek için dışarı çıkar, gezinir. Bir arkadaşına rastlar ve onun daveti üzerine onun evinde verilen bir davete gider. Orada ilk defa gördüğü Mediha adındaki kadına âşık olur. "Işste yirmi senedir aradığım meçhul kadın!” diyerek ona mektup yazmak ister yazamaz bu düşüncelerle üç gün evden dışarı çıkmaz. Arkadaşı Camsap, gelip bu durumu sorgular. Kahraman bunun bir aşk olduğunu söylese de arkadaşı "Sus ulan bunak horoz!... dedi, işte gayet basit bir ilkbahar darbesi!." (Seyfettin, 1999c, 225) der ve onu yirmi dört saat içinde tedavi edeceğini söyler. Bunun için "Evvela baharın tesirini göstermediği soğuk bir yere gideceksin!" iddiasını ileri sürer. Yazar buna uyarak böyle bir yere gider. Soğuğa bir hafta dayanamayan yazar tekrar köşke döner. Her tarafta çiçekler açmış, kelebekler daha da çoğalmıştır. "Mediha'yı düşünmeye kalktım. Odama kapandım. Bir türlü hayalini gözümün önüne getiremedim. Sesini hatırlayamıyordum" (Seyfettin, 1999c, 230) diyerek durumunu açıklar.

Ezeli Bir Roman hikâyesinde ise bir iddianın ileri sürülmesi vardır. Ama burada iddia savunulmaz ancak zamanla hikâyenin kahramanları iddianın doğruluğunu yaşayarak öğrenirler. Yazar olayları öylesini kurgular ki kahramanlar adım adım iddianın doğruluğunu yaşayarak kabullenirler. Âdem Bey ve Havva Hanım birbirlerini çok sevmekte ve hep el ele diz dizedirler. Yine bir gün bahçede birbirlerine aşk yeminleri ederken onları görüp hallerine gülen bir cüce görürler ve niçin güldüğünü sorarlar. Cüce onların haline güldüğünü söyleyince şaşırarak halimizde ne var diye tekrar soralar. Aralarında aşağıdaki konuşma geçer:

“-Yalan söylüyorsunuz. Birbirinizi aldatıyorsunuz!

Havva Hanım 
Türkçe Öğretiminde Eleştirel Düşünmeyi Geliştirme Bakımından Ömer Seyfettin'in Hikâyelerinin Yeri

-Bizim birbirimizi ebedi bir aşkla sevdiğimize inanmıyor musunuz? Diye sordu. Cüce tekrar ebedî bir, kahkaha çınlattı:

-Fani hayat içinde ebedî bir aşk ha?..

-Evet!

-iş̧te en büyük yalan!

Âdem Bey

-Kısa bir hayat uzun bir aşk, derin bir vefa doldurmaz mı? dedi.

-doldurmaz.

-Niçin?

-Çünkü hayat ne kadar kısa ise dakikaları o kadar uzundur!

$\cdots$

-...

Bu sözden ikisi de bir şey anlamadı. Tekrar kucaklaştılar. Cüce dizlerinin dibine yaklaştı. Kalın sesiyle:

"Şimdi böyle can cana,

Fakat sonra yan yana,

En nihayet..."

Dedi. Sözünü tamamlamadı. Yine bir kahkaha attı. Âdem Bey fenalaşan sevgilisini bıraktı. Cüceye döndü, sordu.

-Ee, en nihayet?

-Sen bir yana, o bir yana!" (Seyfettin, 1999c, 68) Kahramanlarımız cücenin dediklerine itibar etmezler evlenirler, her şey diledikleri gibi gitmektedir, sık sık birbirlerine "Can cana değil mi ruhum?" diye sorup "can cana! Ebedîyen..." cevabını verirler. Zamanla Havva Hanım'ın sorusunu Âdem Bey duymamaya başlar. Havva Hanım cücenin "yan yana" sözünü hatırlar. İlerleyen günlerde soğuk bir kış günü Âdem Bey karısına "Yorganları ayıralım. Ben bir yana çekileyim. Rahat rahat uyuyalım!" (Seyfettin, 1999c, 69) der. Havva Hanım, gülümseyerek "-Ben de bir yana... Pekâlâ? "diye cevap verir. Büyük ela gözleri yaşaran Havva Hanım, "-Ah yalanmış! Yalanmış! diye inledi. Âdem Bey gözünü kapar kapamaz rahat uykusuna dalmıştı. Karısının bütün gece devam eden hıçkırıklarını duymadı..." (Seyfettin, 1999c, 70)

Pireler hikâyesinde de baytar önerdiği tedavinin hasta sahibince anlaşılmaması üzerine sen dediğimi yap köpeğin iyileşirse ücretimi getir yoksa gel bana tüh de diyerek eve gönderir. Köpek sahibi köpeği iyileşince baytarın yanına gelince baytar ona şu açıklamayı, savunmayı yapar: "-Siz istersiniz muska... Siz istersiniz... üfürük... Siz istersiniz ilaç! Hâlbuki hastalıkların evvelâ sebeplerini bulmak lâzım. Bu sebep bulununca şifa bulundu demektir! (Seyfettin, 1999c, 312)

\section{Kendini Düzenleme}

Bütün süreçlerin sonunda bireyin kendini bilinçli olarak sorguladığı, düzelttiği ve edindiği eleştirel becerilerini uygulamaya koyduğu süreçtir. Düzeltmek amacıyla çıkarımlar yapmak üzere analiz ve değerlendirme becerilerini uygulamaya koyduğu 
bilişsel etkinliklerini, bu etkinliklerde bulunan ögeleri ve alınan sonuçları gözlemlemesidir.

Kendini düzenleme, kendini bilinçli olarak sorgulama özellikle millî kimliğini inkâr eden kahramanlarda görülür. Bunun en güzel örneği de Fon Sadriştayn'ın Oğlu hikâyesidir. Bu hikâye Fon Sadriştayn'ın Karısı hikâyesinin devamıdır. Birinci hikâyede hikâye kahramanı okulda Serçe Pehlivan diye tanınan Sadrettin'dir. Kahramanımız çok müsrif ve süslenmekten başka bir şey bilmeyen bir Türk kızıyla evlenmiştir. Onun aşırı harcamaları sonucu borç batağına saplanmış bu durumda onu verem yapmıştır. Tebdili hava için Almanya'ya bir arkadaşının yanına gidince Alman kadının ne demek olduğunu anlayıp bir Alman kızıyla evlenip Türkiye'ye dönmüş, rahat ve borçsuz yaşamaya başlamıştır. Bu yeni hayatı bir saat gibi kurulu ve hiç aksamadan çalışmakta ve para da biriktirmektedir. Ömer Seyfettin'in kahramanın Alman kadınla evlendikten sonraki hayatını özellikle abartılı bir şekilde vermiştir. Bunun sebebi Fon Sadriştayn'ın Oğlu hikâyesini okuyunca anlaşılır, kahramanımızda anlar. Bu ikinci hikâye Sadrettin Beyin kendini sorguladığı kendiyle hesaplaştığı bir nevi kendini düzelttiği bölümdür. Bu hikâyede kahramanımız ihtiyarlamıştır ve aşırı oburluğun sonucu nikris sızıları çekmektedir. Türklerin Millî bayramında ilk defa Fon Sadriştayn o güne kadar içinde duymadığı tatlı bir his duyar ve bu heyecanla bu mutlu günü kutlamak için karısıyla dışarı çıkmak ve halkın coşkusuna katılmak ister. Türklerin millî şairi Orhan Bey'in doğduğu günü karısı ile birlikte kutlamak isteyen Fon Sadriştayn'ı karısının "Bu büyük günden bana ne? Sizin kendi bayramını" (Seyfettin, 1999b, 240) cevabı düşündürmeye, kendi geçmişini sorgulamaya sevk eder. "iş̧e yirmi sekiz sene bir çatı altında beraber intiyarladıkları hâlde ruhları birbirine yabancıydı. Aralarında ummanların, karlı şahikaların ayırdığı geçilmez bir hudut var gibiydi" (Seyfettin, 1999b, 240) Bu arada sokaktan geçen gazeteci çocuğu eve çağırarak bütün gazetelerden birer tane satın alarak Orhan Bey ile ilgili haberleri okumaya başlar. Okudukça kendi oğlu aklına gelir ve üzülür. "O da yirmi yedi yaşındaydı. Tahsili için, terbiyesi için o kadar çalıştığı hâlde, onda her faziletin ölümünden başka bir şey elde edememişti" (Seyfettin, 1999b, 245) diye düşünüyor işin içinden çıkamıyordu Oğlu, "Daha küçükken riyakârlığa başlamıştı. Annesine "Ben Almanım! Türkler eşektir." kendisine "Ben Türküm! Almanlığı kabul etmem. " diyerek ikisinin arasında gizli gizli buz dağları yükseltir; sonra yalanla, düzenle her birisinin muhabbetini ayrı ayrı çalar, çaldığı iki muhabbeti sahiplerine karşı birer şantaj aleti yapardı. Fon Sadriştayn, tamamıyla tepesi dökülmüş başını ellerine aldı:-Niçin böyle oldu? Niçin böyle oldu?" (Seyfettin, 1999b, 245) diye diye kendini sorgulamaya başlar. Bu sorgulama onu Orhan Bey'i yetiştiren anneyi tanıma isteği uyandırır. "Acaba annesi nasıl ulvî, nasıl yüksek, nasıl mükemmel bir kadındı? Oğlunu ilhamın, hayatın, hakikatin tabii membalarına götüren koca bir millete halaskâr yapacak kadar millî bir terbiye veren bu kadın acaba nasıl bir vücuttu? İhtiyar Fon Sadriştayn, içinde ruhuna akseden bu sualleri düşüne düşüne zayıf dimağını yordu" (Seyfettin, 1999b, 246) Görüldüğü gibi Fon Sadriştayn, yaşadıklarından ve olumlu örnekten etkilenerek kendini sorgulamaya bir çeşit düzeltmeye gidiyor.

Kendini sorgulama ve yeniden düzenleme Primo Türk Çocuğu hikâyesinde de görülür. Hikâyenin kahramanı Türklükten nefretiyle tanınan Paris'te tahsil gören dönünce İzmir'de yüksek dolgun bir maaşla çalışan ve İtalyan bir kızla evlenen Kenan Bey'dir. O, Selanik'teki İtalyan Mason Locası'na mensuptur, çocuğuna İtalyan isim verir on yıldan beri de Selanik'te bir İtalyan gibi yaşar ve bundan hiç rahatsız değildir. Italya'nın Trablus'a saldırması harp haberleri Kenan Bey'in kendini sorgulamasına sebep olmuştur. Daha önce önem vermediği hatta pek tabiî gördüğü hareketleri sorgulamaya başlar. Öncelikle "Ah, insaniyete hizmet eden Avrupalılar!" diyerek 
Avrupalıların Afrika ve Asya'yı nasıl sömürgeleştirdiklerini anlıyor ve "Bu nasıl insaniyet idi? Bu insaniyetin vahşilikten, barbarlıktan, yamyamlıktan ne farkı vardı!... (Seyfettin, 1999a, 168) sonucuna ulaşıyordu. Avrupalıların bu şekilde Türkiye'yi taksim edeceklerini anlıyor, bu amaçla ülkemizden koparılan, Bosna-Hersek, Makedonya, Arnavutluk vb. gibi meseleler üretip, bunları çözmek bahanesiyle bu yerleri ülkemizden koparacaklarını düşündükçe kalbi sıkışıyor, kendi kendine kızıp duruyordu: "Bütün hayatında ne kadar yanlış ve çürük fikirlerle aldandığını, kavmiyetsizliğin, milliyetsizliğin, "beynelmilliyetçilik ve masonluk" hülyasının biraz düşünebilen bir adamı hüngür hüngür ağlatacak derecede gülünç bir budalalık olduğunu anlıyor, istemeyerek, içinden: -Ben neyim?... diye kendi kendine soruyor, fakat:-Türküm!... demeye cesaret edemiyor, şimdiye kadar zapt olunmuş kıymetsiz bir cesetten başka bir şey olmadığını idrak ile hiddetinden ve utanmasından ağlamak istiyordu" (Seyfettin, 1999a, 170) Evini eşyalarını hatırladıkça da "Düşünüyor, düşünüyor, düşündükçe iki gündür farkına vardığı mevcudiyetinin aşağılığını, sefaletini, adiliğini, mefkuresizliğini anlıyor; kaybettiği kavmiyeti, unuttuğu milliyeti, kıymetini takdir edemediği esasları için acı bir matem duyuyor: -Ah ne zavallı imişim!" (Seyfettin, 1999a, 178) diyerek hayıflanıyordu. Artarak devam eden bu sorgulama Kenan Bey'i yeni kararlar almaya ve kendini düzenlemeye yani Türk kimliğinden nefret etmemeğe bilakis gurur duymaya götürür. Karısının buradan gitmek fikrini kabul etmez ve ona şu teklifte bulunur: "Benimle yaşamak, evimizi bozmamak istersen tamamıyla Türk olacaksın! İsmin değişecek! Çarşaf giyecek, Türkçe öğrenecek, bir harf İtalyanca söylemeyeceksin..." (Seyfettin, 1999a, 185) Karısı bu teklifi kabul etmez. Çocuklarına kiminle kalmak istediklerini sorunca, babasından önce okuldaki arkadaşları tarafından gerçeği görüp kendi kimliğine sahip olan Primo "Ben... Turko çocuk... Ben, yok İtalyano... Ben burada... Ben çocuk Türk..." (Seyfettin, 1999a, 187) diyerek cevabını verir. Artık Kenan ve Primo için kendilerini düzenleyecekleri yeni hayatları bu hikâyenin devamı olan Primo Türk Çocuğu (nasıl doğdu, nasıl öldü) adlı hikâyede anlatılır.

Bu hikaye baştan sona baba oğlun kendi kimliklerinin farkına varma ve kendilerini ona göre düzenleme çabalarının dile getirilmesidir. illk düzenleme Primo'ya Türkçe Oğuz ismini vermekle başlar (Seyfettin, 1999a, 265) ikinci düzenleme evdeki Rum uşak, aşçı ve hizmetçilerin yerine Türk aşçı, hizmetçi ve uşak bulunmasıdır (Seyfettin, 1999a, 266) Bundan sonra Oğuz ve babası bir Türk gibi yaşayarak ülkenin problemleriyle ilgilenirler.

Kendini düzenleme Niçin zengin Olmamış adlı hikâyede de vardır. Hikâye günlük şeklinde düzenlenmiştir. Hikâyenin sağ üst köşesinde "Bir Sultanî mualliminin hatırat defterinden üç dört sayfa" ifadesi ve 7 Kanun-ı sani 1916 tarihi belirtilmiştir. Hikâyede muharebe zamanında bir Sultani mualliminin geçim sıkıntısı çekerken eski bir okul arkadaşına rastlayıp onun sayesinde zengin olup lüks içinde yaşaması ve sonra halkı dolandırarak zengin olduklarını anlayınca, zenginlikten vazgeçip eski hayatına geri dönmesi anlatılır. Eserin adının da Niçin Zengin Olmamış" konması dikkat çekicidir. Hikâye kahramanının yolu zengin olduktan sonra bir gün eski oturduğu mahallesine düşer. Mahalle viraneye dönmüştür. Sokaklarda kimsecikler yoktur. Sadece üstü başı perişan dört kişi bir şeyler aramaktadır. Kahramanımız bunların ne aradıklarını merak eder ve sorar. " Merak ettim. Ne arıyorlardı? Yürüdüm. Yanlarına yaklaştım. Ne aradıklarını sordum.

-Ölü arıyoruz! Dediler

-Ne ölüsü?

-İnsan ölüsü. 
-İnsan ölüsü mü?

-Evet...

Şaştı̆ıımı görünce durdu. Beni baştan aşağıya bir süzdü. Sonra başını salladı: hey gidi, hey! dedi, efendi senin de haberin yok galiba? Biz belediye adamlarıyız. Her gün gelip buralarda açlıktan ölenleri toplarız, sonra şu arabaya doldururuz. Götürürüz, gömeriz. Açlıktan ölüyorlar ha... Buz gibi dondum” (Seyfettin, 1999c, 190) Konuşmanın devamında kahramanımız milleti böyle açlıktan ölmeye terk eden kimseleri öğrenir. Bunlar "Millete ekmek diye kum toprak yedirenler! Katığı dünya yüzünden kaldıranlar! Fıkarayı soyup kendileri zengin olanlar! Otomobillerde ucanlar!" (Seyfettin, 1999c, 191) dır. Bunun üzerine kendi durumunu sorgulayan kahramanımız "Evet insanları böyle açlıktan öldüren bizdik! Bize yol gösteren; bize müsaade edip, bizimle beraber çalışanlar! (Seyfettin, 1999c, 191) diye düşünerek kendi kendiyle iç hesaplaşmasına girer ve kendini yeniden düzenler. Hikâye kahramanının kendini yeniden düzenlemesi gördüklerini ve işittiklerini değerlendirip çıkarımlarda bulunmasıyla gerçekleşmiştir. En iyi öğrenme İnsanın kendi kendine görerek işiterek öğrenmesi ve değişime kendinin karar vermesidir. Bunu için hikâyenin kahramanı hayatını yeniden düzenleyebilir. Bu hikâye de öğrencilerin kendi hayatlarını yeniden düzenlemelerine örnek teşkil edebilir, öğrenciler bu hikâyeden hareketle her zaman hatadan dönülebileceğini öğrenebilirler. Yine hikâye sayesinde kendi yakın çevrelerine daha duyarlı bakabilir çevrelerinde olan bitenden haberdar olabilirler.

\section{Tartışma ve Sonuç}

Günümüzde öğretim kurumlarından beklenen şeylerin başında, bireylere eleştirel düşünme becerilerini kazandırmak gelmektedir. Çünkü öğrenciler ancak bu yolla kendilerine sunulan bilgiyi çözümleyebilir, bilgiyi nasıl kullanacağını bilir ve bunlardan yeni bilgiler üretebilir. "Eleştirel düşünme eğitimi, eğitim süreçlerinin bir parçası olması halinde; öğrencilerin hem akademik açıdan daha başarılı hem de bilgilerinde işlevsel olarak yararlanabilmeleri sağlanabilir" (Elias ve Kress, 1994'ten aktaran Korkmaz, 2009:20). Dolayısıyla eleştirel düşünme becerisini kazanan birey her ortamda bunu kullanarak karşılaştığı problemleri çözebilir. Türkçe dersi, öğrencilere eleştirel düşüncenin kazandırılmasında en çok katkı sağlayan derslerden biridir.

Dil becerilerini geliştirmenin düşünme becerilerini geliştirmek olduğunu belirten Wittgenstein, "Dilimin sınırları düşüncemin sınırları" (Akarsu, 1998) diyerek dil düşünce ilişkisine vurguda bulunur. Uygur (1994:137) da "Dilim düşüncemi, düşüncem de dilimi yoğuruyor" derken aynı noktaya dikkat çeker. Dil öğretiminin temel aracı ise metinlerdir (Baş, 2003:258). Ülkemizde çoğu zaman ders kitaplarında sunulan metinler tek kaynak olarak kullanıldığı için metinlerin önemi daha da artmaktadır. Bu sebeple Türkçe öğretiminde kullanılacak metinlerin niteliği birçok araştırmanın konusunu oluşturmuştur (Cemiloğlu ve Kolaç, 2003; Çalışkan, 2006; Duman, 2010; Aytaş, 2002; Küçük ve Gökdağ, 1998; Şen, 2004; Baş, 2003). Son yıllarda ise Türkçe dersinde kullanılan metinler ya da belirlenen metinler, yaratıcılık, eleştirel düşünce, problem çözme ve değerler öğretimi yönünden araştırılmıştır (Temizkan, 2011; Karatay, 2007; Karatay, 2011; Özdere, 2011; Başoğlu ve Mutlu, 2012; Cihaner, 2007; Kurudayıoğlu, Tüzel ve Karakaş, 2011;Kurudayıoğlu,Çelik,2009; Kurudayıoğlu,Çelik,2011). Bu konudaki çalışmalar gittikçe de çeşitlenerek devam etmektedir. 
Ömer Seyfettin'in birçok hikâyesinin eleştirel düşünmenin özelliklerini büyük ölçüde taşıdığı tespit edilmiştir. Yapılan araştırmalar da öğrencilerin onun hikâyelerini severek okuduklarını göstermektedir. Bu sebeple onun hikâyeleri Türkçe dersinde metin olarak kullanılmalı ve bu hikâyelerdeki eleştirel düşünme özellikleri bu yönüyle de incelenmelidir. Her zaman hikâyelerin tamamı incelenmeyebilir. Uygun durumlarda hikâyelerin örnek teşkil eden bölümleri anlam bozulmadan eleştirel düşünme örneği olarak öğrencilere sunulabilir. Mesela hikâyedeki sorgulamanın yapıldığı ve gerçeğin ortaya çıkarıldığı bölümlere dikkat çekerek sorgulamanın nasıl yapıldığı, gerçeğe nasıl ulaşıldığı öğrencilerle sorgulanarak belirlenebilir. Buradan hareketle öğrenciler gerçek bilgiye nasıl ulaşılacağını öğrenir ve kendileri de bu çıkarımı yapabilirler. Öğrencilerin kolayca anlayacağı hikâyelerden olan Perili Köşk, Kurbağa Duası ve Pireler gibi hikâyeler öğretmenin rehberliğinde yeniden kurgulanarak hikâyelerdeki eleştirel düşüncenin örneği gösterilebilir. Mesela Kurbağa Duası hikâyesinde yazar Bahir Hocanın Kurbağaları nefes ederek susturduğu iddiasını hiç sorgulamasa gerçeği ortaya çıkarmasa ne olurdu gibi sorularla kurgulatabilir. Bu durumda öğrenciler demek ki işitilen bir bilgiyi hemen kabul etmemeli, araştırmalı çıkarımında bulunabileceklerdir. Aynı şey Perili Köşk için de yapılabilir. Ev sahibinin kiracıları kaçırmak için uydurduğu hain plana Sermet Bey inansaydı neler olurdu ve inanmayıp işin aslını araştırınca ne oldu gibi sorularla öğrencilere eleştirel düşünme becerileri kazandırılabilir. Bu kazanım ezber şeklinde değil de öğrencilerin metinden çıkarımları şeklinde olduğu için de kalıcı ve etkili öğrenme gerçekleştirilmiş olabilir.

Fon Satdriştayn'ın Oğlu, Primo Türk Çocuğu, gibi hikâyeler sayesinde öğrencilerde kimlik bilinci de geliştirilebilir. Öğrenciler hikâye kahramanlarıyla kendilerini özleştirebilirler. Kahramanların kendilerini sorguladıkları bölümleri okurken onlar da kendilerini sorgulayacaklardır. Daha da iyisi öğretmen sorusuyla öğrencilerin kendilerini sorgulamalarını sağlayabilir. Kendini sorgulamak eleştirel düşüncenin kendini düzenleme adımına götürür öğrencileri.

Ömer Seyfettin'in hikâyelerinde eğitici değerler de çok yüksektir. İdeal sahibi vatandaşlara sahip olmak devletlerin en önemli hedeflerinden biridir. İlk Düşen Ak hikâyesinde bir ideal sahibi olmanın önemi hikâye kahramanının başından geçen olaylar dizisi şeklinde gösterilir. Bu hikâyeyi okuyan öğrenciler bir insanın bir ideali olmasa mutlu olamayacağını, mutsuz olacağını görebilir ve kendi ideallerine sıkı sıkıya sarılabilirler. Niçin Zengin Olmamış hikâyesini okuyan öğrenciler duyarlı vatandaş olmanın, kendi kendilerini sorgulamanın gereğini öğrenirler. Çevrelerinde olan bitenlere daha dikkatli bakıp üzerlerine düşen sorumluluğu üstlenebilirler.

Ömer Seyfettin'in hikâyelerinde yapılan isabetli değerlendirmeler tam bir eleştirel düşünme örneğidir. Bu değerlendirmeler öğrencilere gösterilerek, bu değerlendirmenin hangi bilgilerden elde edildiği, bu değerlendirmeye nasıl ulaşıldığı ve değerlendirmenin dayanakları buldurularak öğrencilerin benzer durumlarda da aynı şekilde sağlam değerlendirmeler yapması sağlanabilir. Mesela Pembe İncili Kaftan hikâyesi bunun için kullanılabilir. Hikâyedeki durumun ortaya konması çözüm için en uygun elçi adayının seçilmesi, hikâyenin sonunda bu değerlendirmenin ne kadar isabetli olduğunu görülmesi hep eleştirel düşünmenin adımları olarak incelenebilir.

Ömer Seyfettin'in hikâyelerinin metin olarak Türkçe dersinde kullanılması öğrencilerin hem okuma alışkanlığı kazanmalarına hem eleştirel düşünme becerileri kazanmalarına dolayısıyla Türkçenin inceliklerini öğrenmelerine hem de hayatı tanımalarına katkı sağlayacaktır. Çünkü Ömer Seyfettin, hem Türkçeyi çok iyi kullanır hem de hikâyelerinde sosyal hayatımızı çok iyi yansıtır. 


\section{Kaynakça}

Adalı, O. (2004). Anlamak ve anlatmak. İstanbul: Pan Yayıncılık.

Akarsu, B. (1998). Dil-kültür bağlantısı. İstanbul: İnkılâp Kitabevi.

Akınoğlu, O. (2001). Eleştirel düşünme becerilerini temel alan fen bilgisi öğretiminin öğrenme ürünlerine etkisi. Yayınlanmamış Doktora Tezi, Hacettepe Üniversitesi Sosyal Bilimler Enstitüsü, Ankara.

Aldağ, H. (2006). Toulmin tartışma modeli. Çukurova Üniversitesi Sosyal Bilimler Enstitüsü Dergisi, 15 (1), 13-34.

Aksu, M.(1996). Nasıl bir insan? Nasıl bir öğretim?. Yeni Türkiye Dergisi.Eğitim ,2,101-105.

Aytaş, G. (2001). Türkçe ders kitaplarının yazımında metin seçimi ve metin altı sorularının hazırlanmasında dikkat edilmesi gereken bazı hususlar. Türk Yurdu Dergisi(Türkçeye Saygı Özel Sayısı), 21, 162-163.

Baş, B. (2003). Altıncı sınıf Türkçe ders kitaplarındaki metin türleri üzerine bir inceleme.. Türklük Bilimi Araştırmaları Dergisi, 13, 257-266.

Başoğlu, N. Mutlu, B. (2012). İlköğretim Türkçe ders kitaplarında yer alan metinlerin eleştirel düşünme eğitimine uygunluğu. Kastamonu Eğitim Dergisi, 20(3), 983-998.

Battal, N. ve Bilen, M. (Ed.). (2010). Eğitimde ilke ve yöntemler. Ankara: Betik Kitap.

Cemiloğlu, M. Kolaç, E. (2003). İlköğretim dördüncü sınıf Türkçe ders kitaplarının öğretmen görüşlerine dayalı olarak incelenmesi. Uludağ Üniversitesi Eğitim Fakültesi Dergisi, XVII (1), 105-137.

Cihaner, C. (2007). Eleştirel düşünme kazandırma yönüyle Bilgin Adalı'nın çocuk kitapları. Yayınlanmamış Yüksek Lisans Tezi, Abant İzzet Baysal Üniversitesi Sosyal Bilimler Enstitüsü, Bolu.

Çalışkan, N. (2006). Türkiye'deki orta öğretim edebiyat ders kitapları üzerine edebiyat eğitimi açısından bir değerlendirme. Millî Eğitim Dergisi, (34)169,

Çiftçi, M. (1998). Türkçe öğretiminde temel ilkeler. Kocatepe Üniversitesi Sosyal Bilimler Dergisi, 1, 59-71.

Duman, A. (2010). Türkçe eğitiminde metne müdahale sorunu. Türklük Bilimi Araştırmaları Dergisi (Türkçe Öğretimi Özel Sayısı), 27, 285-295.

Engünün, İ. (1985). Ömer Seyfettin'in hikâyeciliği, doğumunun yüzüncü yılında Ömer Seyfettin. Ankara: Türk Tarih Kurumu Basımevi.

Gündoğdu, H. (2009). Eleştirel düşünme ve eleştirel düşünme öğretimine dair bazı yanılgılar. Celal Bayar Üniversitesi Sosyal Bilimler Dergisi, 7(1), 57-74.

Geçgel, H. (2007). Ömer Seyfettin hikâyelerinin ilköğretim programında kullanılabilirliği, http://www.izedebiyat.com/yazi.asp?id=62632 (Erişim Tarihi:01.11.2012)

Karadüz, A. (2010). Dil becerileri ve eleştirel düşünme. Turkish Studies, 5(3), 1566-1593.

Karasar, N. (2009). Bilimsel araştırma yöntemi. Ankara: Nobel Yayın Dağıtım.

Karatay, H. (2007). Dil edinimi ve değer öğretimi sürecinde masalın önemi ve işlevi. Türk Eğitim Bilimleri Dergisi, 5(3), 463-475.

Karatay, H. (2011). Karakter eğitiminde edebi eserlerin kullanımı. Turkish Studies, 6(1), 13981412.

Kazancı, O. (1989). Eğitimde eleştirici düşünme ve öğretimi. Ankara: Kazancı Hukuk Yayınları.

Kırkkılıç, A. Akyol, H. (Ed.) (2007). Ilköğretimde Türkçe öğretimi. Ankara: Pegem Akademi Yayıncılık.

Korkmaz, O. Yeşil, R.(2009). Öğretim kademelerine göre öğrencilerin eleştirel düşünme düzeyleri. Ahi Evran Üniversitesi Kırşehir Eğitim Fakültesi Dergisi (KEFAD), 10(2), 19-29.

Korkmaz, Ö. (2009). Eğitim fakültelerinin öğrencilerin eleştirel düşünme eğilim ve düzeylerine etkisi. Türk Eğitim Bilimleri Dergisi, 7(4), 879-902.

Kökdemir, D. (2002).Öğretmen adaylarının eleştirel düşünme gücü. Yayınlanmamış Yüksek Lisans Tezi, Anadolu Üniversitesi Eğitim Bilimleri Enstitüsü, Eskişehir. 
Kökdemir, D. (2003). Belirsizlik durumlarında karar verme ve problem çözme. Yayımlanmamış Doktora Tezi, Ankara Üniversitesi Sosyal Bilimler Enstitüsü, Ankara.

Küçük, S. Gökdağ, B.A. (1998). MEB ilköğretim 1.kademe Türkçe ders kitapları üzerine bir inceleme denemesi. Dil Dergisi, 73, 5-14.

Kürüm, D. (2002). Öğretmen adaylarının eleştirel düşünme gücü. Yayımlanmamış Yüksek Lisans Tezi, Anadolu Üniversitesi Eğitim Bilimleri Enstitüsü, Eskişehir.

Kurudayıŏlu,M.Tüzel,S.Karakaş,Ö.(2011). Türkçe ders kitaplarında yer alan metinlerdeki düşünceyi geliştirme tekniklerinin incelenmesi. Abant lzzet Baysal Üniversitesi, Eğitim Fakültesi Dergisi,11(2),183-204.

Kurudayığlu,M,Çelik,G,(2009). Türk edebiyatı derslerinde eleştirel düşünme eğitimi.Hitit Üniversitesi,Sosyal Bilimler Enstitüsü Dergisi,1(2),79-92.

Kurudayığlu,M,Çelik,G,(2011).9.sınıf Türk edebiyatı programının eleştirel düşünce açısından öğretmen görüşlerine göre değerlendirilmesi. Mustafa Kemal Üniversitesi Sosyal Bilimler Enstitüsü Dergisi, 8(15), 213-237..

MEB (2006). Türkçe Dersi (6, 7, 8. Sınıflar) öğretim programı ve kılavuzu. Ankara: MEB Yayınları.

Önertoy, O. (1985). Ömer Seyfettin'in milliyetçilik düşüncesi, doğumunun yüzüncü yılında Ömer Seyfettin. Ankara: Türk Tarih Kurumu Basımevi.

Özcan, G. (2007). Problem çözme yönteminin eleştirel düşünme ve erişiye etkisi. Yayınlanmamış Doktora Tezi, Abant İzzet Baysal Üniversitesi Sosyal Bilimler Enstitüsü, Bolu.

Özdemir, S. M. (2005). Web ortamında bireysel ve işbirlikli problem temelli öğrenmenin eleştirel düşünme becerisi, akademik başarı ve internet kullanımına yönelik tutuma etkileri. Yayımlanmamış Doktora Tezi, Gazi Üniversitesi Eğitim Bilimleri Enstitüsü, Ankara.

Özden, Y. (1999). Öğrenme ve öğretme. Ankara: Pegem Yayıncılık.

Özdere, Ö. (2011). Illköğretim birinci kademe Türkçe ders kitaplarındaki öyküleyici metinlerde düşünme becerilerinin incelenmesi. Yayımlanmamış Yüksek Lisans Tezi, Marmara Üniversitesi Eğitim Bilimleri Enstitüsü, İstanbul.

Seferoğlu S. Akbıyık C. (2006). Eleştirel düşünme ve öğretimi. Hacettepe Üniversitesi Eğitim Fakültesi Dergisi. 30, 193-200.

Semerci, N. (1999). Kritik düşünmenin mikro öğretim dersinde eleştiri becerisini geliştirmeye etkisi. Yayımlanmamış Doktora Tezi, Fırat Üniversitesi Sosyal Bilimler Enstitüsü, Elazığ.

Semerci, N. (2000). Kritik düşünme ölçeği. Eğitim ve Bilim, 25(16), 23-26.

Seyfettin, Ö.(1999a). Bütün eserleri hikâyeler 1.( Haz: Hülya Argunşah). İstanbul: Dergâh Yayınları.

Seyfettin, Ö.(1999b). Bütün eserleri hikâyeler 2.( Haz: Hülya Argunşah). İstanbul: Dergâh Yayınları.

Seyfettin, Ö.(1999c). Bütün eserleri hikâyeler 3 .( Haz: Hülya Argunşah). İstanbul: Dergâh Yayınları.

Seyfettin, Ö.(1999ç). Bütün eserleri hikâyeler 4.( Haz: Hülya Argunşah). İstanbul: Dergâh Yayınları.

Sezer, A. (1993). Illetişim araçlarının dil gelişimine etkisi, Ilköğretim Okullarında Türkçe Öğretimi ve Sorunları Bildirisi, (Ed.F.Oğuzkan) Ankara: Türk Eğitim Derneği Yayınları, 93-121.

Şahinel, S. (2001). Eleştirel düşünme becerileri ile tümleşik dil becerilerinin geliştirilmesi. Yayımlanmamış Doktora Tezi, Gazi Üniversitesi Eğitim Bilimleri Enstitüsü, Ankara.

Şen, Ü. (2008). Altıncı sınıf türkçe ders kitaplarındaki metinlerin ilettiği değerler açısından incelenmesi. Uluslararası Sosyal Araştırmalar Dergisi, 1(5), 763-779. 
Şen, Ü. (2009). Türkçe öğretmeni adaylarının eleştirel düşünme tutumlarının çeşitli değişkenler açısından değerlendirilmesi. Zeitschrift für die Welt der Türken Journal of World of Turks, 1 (2), 69-89.

Şimşek, Y. (2008). Ömer Seyfettin'in hikâyelerinde çocuklara yönelik öğretici öğeler. 2.Dünden Bugüne Ömer Seyfettin Sempozyumu (7-9 Mart 2008) Bildirileri, (Ed.R.Duymaz)Gönen: Gönen Belediyesi Kültür Yayınları,139-152.

Tansel, F.A. (1985). Ömer Seyfettin'in ilk eserleri ve şiirleri, doğumunun yüzüncü yılında Ömer Seyfettin. Ankara: Türk Tarih Kurumu Basımevi.

Temizkan, M. (2011). Türkçe öğretiminde yaratıcı düşünmeyi geliştirme bakımından Nasreddin Hoca fıkraları. Mustafa Kemal Üniversitesi Sosyal Bilimler Enstitüsü Dergisi, 8(16), 195-223.

Tok, E. (2008). Düşünme becerileri eğitim programının okul öncesi öğretmen adaylarının eleştirel, yaratıcı düşünme ve problem çözme becerilerine etkisinin incelenmesi. Yayımlanmamış Doktora Tezi, Marmara Üniversitesi Eğitim Bilimleri Enstitüsü,İstanbul.

Tosunoğlu, M. Haktanır, G. Çocuk, H. E. ve Gök, Z. (2008). Ilköğretim ikinci kademe öğrencilerine göre Ömer Seyfettin. 2.Dünden Bugüne Ömer Seyfettin Sempozyumu (7-9 Mart 2008) Bildirileri, (Ed.R. Durmaz)Gönen: Gönen Belediyesi Kültür Yayınları, 179191.

Tural, N. (1998). Planlı dönemde temel eğitim ve lise seviyesi eğitimin yeniden düzenlenmesi ile ilgili politikalar. Ankara: DPT.

Uygur, N. (1994). Dilin gücü. Ankara: Yapı Kredi Yayınları.

Yalçın, A. (2002). Türkçe öğretim yöntemleri. Ankara: Akçağ Yayınları.

Yapıcı, M.(2004). Ilköğretim 1.kademe ders kitaplarının öğrenci düzeyine uygunluğu. Uluslararası Sosyal Araştırmalar Dergisi, 1(1), 121-130.

Yıldırım, H.i. Şensoy, Ö. (2011). Illköğretim 7. sınıf öğrencilerinin eleştirel düşünme eğilimi üzerine eleştirel düşünme becerilerini temel alan fen öğretiminin etkisi. Kastamonu Eğitim Dergisi, 19(2), 523-540. 